\title{
Spatial aspects of regional infrastructure distribution (the case of Sverdlovsk region)
}

\author{
Ju. G. Lavrikova ${ }^{1} \bowtie$, A. V. Suvorova ${ }^{1,2}$ \\ ${ }^{1}$ Institute of Economics, Ural Branch of the Russian Academy of Sciences, Ekaterinburg, Russia; \\ e-mail: lavrikova_ug@mail.ru \\ ${ }^{2}$ Ural State University of Economics, Ekaterinburg, Russia
}

\begin{abstract}
The article discusses the correlation between the localization of specific infrastructure objects within a region and characteristics of this region's territorial development. Conceptually the study is grounded in the theory of regional economics, spatial analysis and modelling and uses the tools of spatial autocorrelation analysis, such as the global and local Moran's I, and map-based spatial analysis. The settlement system of Sverdlovsk region (Russia) is considered as a key characteristic of its territorial development and the analysis shows the correlation between settlement patterns and the distribution of certain objects of social infrastructure (places of attraction) across the region's territory. Access to infrastructure is an important factor which attracts people to this or that municipality. However, the key parameter that determines the spatial aspects of infrastructure distribution in the region is the emergence and development of the factors underlying this process. The article demonstrates that the localization of infrastructure objects built to generate economic effects and bring profit to their developers to a greater extent correlates with the prospective transformations of the settlement system (primarily agglomeration processes) rather than with its current characteristics (such correlation is more typical of the infrastructure objects specifically intended to address social issues). These research findings can be used by policy-makers for setting priorities of regional development, which would shape the spatial transformations of the territory.
\end{abstract}

\section{KEYWORDS}

space, settlement system, distribution, social infrastructure, region, spatial autocorrelation, Moran's I, map-based spatial analysis, Sverdlovsk region

\section{ACKNOWLEDGEMENTS}

The research was supported by the Institute of Economics, Ural Branch of the Russian Academy of Sciences in accordance with the plan for 2019-2021.

\section{FOR CITATION}

Lavrikova Ju. G., Suvorova A. V. (2019) Spatial aspects of regional infrastructure distribution (the case of Sverdlovsk region). R-economy, 5(4), 155-167. doi: 10.15826/recon.2019.5.4.016

\section{Пространственные аспекты инфраструктурного обустройства региона: пример Свердловской области}

\author{
Ю. Г. Лаврикова ${ }^{1} \bowtie$, А. В. Суворова ${ }^{1,2}$ \\ ${ }^{1}$ Институт экономики Уральского отделения Российской академии наук, г. Екатеринбург, Россия; \\ e-mail: lavrikova_ug@mail.ru \\ ${ }^{2}$ Уральский государственный экономический университет, г. Екатеринбург, Россия
}

\section{АННОТАЦИЯ}

Статья посвящена оценке степени соответствия характера размещения в пространстве региона элементов инфраструктуры особенностям его территориального развития. Теоретическую и методологическую основу исследования составляет совокупность научных представлений в области региональной экономики, пространственного анализа и моделирования. На основе оценки пространственной автокорреляции (с помощью определения величин как глобального, так и локального индекса Морана) и осуществления картографического анализа выделены и сопоставлены друг с другом особенности сложившейся в Свердловской области системы расселения (как одной из ключевых характеристик ее территориального развития) и взаиморасположения в регионе элементов инфраструктуры мест проживания и мест притяжения. Показано, что размещение объектов социальной инфраструктуры в целом соответствует характеру расположения на территории ее основных потребителей - жителей региона. Однако ключевым параметром, определяющим пространственные аспекты инфраструктурного обустройства территории, является генезис факторов, лежащих в основе данного процесса. Доказано, что локализация инфраструктурных объектов, главной целью создания которых

\section{КЛЮЧЕВЫЕ СЛОВА}

пространство, система расселения, размещение, социальная инфраструктура, регион, пространственная автокорреляция, индекс Морана, картографический анализ, Свердловская область

\section{БЛАГОДАРНОСТИ}

Работа выполнена при поддержке Института экономики Уральского отделения Российской академии наук в соответствии с планом на 2019-2021 гг. 
выступает генерация экономических эффектов и получение прибыли, в большей степени коррелирует не с текущими особенностями системы расселения (что характерно для объектов, создание которых призвано способствовать решению социальных проблем), а с перспективами ее преобразования, проявляющимися тенденциями (в первую очередь, с агломерационными процессами). Полученные результаты могут найти применение при определении приоритетов осуществления региональной политики, пространственных преобразований территорий.

\section{ДЛЯ ЦИТИРОВАНИЯ}

Lavrikova Ju. G., Suvorova A. V. (2019) Spatial aspects of regional infrastructure distribution (the case of Sverdlovsk region). R-economy, 5(4), 155-167. doi: 10.15826/recon.2019.5.4.016

\section{Introduction}

The distribution of infrastructure elements across space is one of the main topics not only in regional economics and economic geography but also in policy-making on different levels of the territorial hierarchy. The principal difficulty is to determine the parameters for the optimal location of such infrastructure objects.

It seems obvious that the key criterion should be the ability of infrastructure objects to meet the needs of the main stakeholders, regardless of the level of the territory - cities, regions or the country as a whole. It means that the distribution of infrastructure should correlate with the concentration of its users, that is, the latter should be provided with a convenient access to these objects. Developed infrastructure, in its turn, attracts more residents to the area, which is conducive to socio-economic growth and turns infrastructural development into a powerful tool of regional policy-making. Irrespective of whether the infrastructure is going to be developed in accordance with the already existing settlement patterns and distribution of productive forces across the territory or with the view to future transformations of the socio-economic space, decision-making in this sphere is based primarily on the analysis of the current situation: before building new objects of infrastructure, it is necessary to assess different parameters of the region's development, in particular the already existing infrastructure, and identify the gaps and disproportions that need to be addressed.

This study is aimed at analyzing the characteristics of territorial development of a region and revealing their correlation with the localization of infrastructure objects in the given area. It should be noted that such analysis should take into account different types of infrastructure. Our study focuses on the discrepancies between settlement patterns of a region (characteristics of its territorial development) and localization of some elements of social infrastructure in the same region (infrastructure necessary for maintaining and improving the living conditions).

\section{Theoretical framework}

Spatial aspects of economic development now attract considerable scholarly attention in Russia, especially after the adoption of the federal law 'On Strategic Planning in the Russian Federation'1 in 2014. This law identifies the strategy of spatial development as one of the key strategic planning documents.

However, it should be noted that the research on the relationship between the distribution of economic entities across space and specific parameters of territorial development goes back to the nineteenth century. The classical location theory developed by J. H. von Thünen [1], A. Weber [2], A. Lösch [3], W. Christaller [4], and C. W. F. Launhardt [5] described the factors that determine the localization of industries in space. Spatial aspects of territorial development were also considered by the growth poles theory and the theory of polarized development, theories and concepts of urban development [8;9], and so on.

Questions related to distribution of productive forces were also discussed by Soviet economists, such as N.N. Nekrasov [10], I. G. Alexandrov [11], A.E. Probst [12] and others. Interestingly enough, as A.I. Tatarkin and E. G. Animitsa point out in their article on the paradigm theory of regional economy, seminal works written by Western authors had little impact on the theoretical views of Soviet scholars in what concerned the distribution of industrial enterprises and regional development. Nevertheless, the development of territorial studies in the USSR, which dealt primarily with the radical shifts in the location of productive forces, theory and practice of economic zoning, factors that determine the location of industries, to some extent coincided with the international trends.

The research of the role played by spatial factors in the development of socio-economic systems requires a methodological approach that would not rely exclusively on evaluating the dy-

${ }^{1}$ Federal Law No. 172-FZ of 06.26.2014 'On Strategic Planning in the Russian Federation'. Retrieved from: http:// www.consultant.ru/document/cons doc LAW 164841 
namics of certain objects in time but consider the specific parameters of these objects' distribution across space, that is, the proximity of objects to each other, their concentration within one area and the scale of the systems they form. Therefore, such studies prioritize methods of spatial analysis and modelling.

Without going into a detailed discussion of the history of spatial analysis, we need to mention that this methodology goes back to the 1940s and 1950s, when the first papers on spatial modelling were published $[14 ; 15]$. At the subsequent stages $[16 ; 17]$, more new methods for estimating the spatial effects produced by the transformations on different levels were proposed. These methods provided sufficient foundation for a vast number of empirical studies, including the studies based on Russian data.

Spatial autocorrelation analysis has been gaining popularity among Russian scholars [18-22]. Spatial autocorrelation can be defined the following way: for set $S$ containing $n$ geographical units, spatial autocorrelation is a correlation between the variable observed in each of the $n$ localities and a measure of geographical proximity defined for all $n(n-1)$ pairs chosen from $S$ [23]. In other words, spatial autocorrelation analysis shows the strength of correlation between the parameters characterizing the development of territories located in close proximity to each other.

One of the most widely applied (and relatively easy to use) parameters is Moran's I. The test for spatial autocorrelation proposed by Patrick Moran is used in most Russian studies of patterns of spatial dependence between neighbouring territories. Various indicators can be used to describe the situation in the given territories: for example, Y. V. Pavlov and E. N. Koroleva analyzed territorial clusters in Samara region by looking at the population data of its municipalities [18]. A. A. Grigoriev estimated the scale of spatial autocorrelation in Russian regions by using such parameters as education, crime rates, birth rates, infant mortality rates, urbanization, migration, urbanization and household income [19]. O. A. Demidova focused on the level of unemployment [20]; O.S. Balash, on the GRP per capita [21]; E. S. Inozemtsev and O. V. Kochetygova, on birth rates and life expectancy [22].

If we look at the theoretical and methodological foundations of Russian and international studies of economic space, we can see that spatial analysis methods hold enormous potential as they help us search for correlations between various parameters of territorial development and the localization of infrastructure within this territory.

\section{Methodology and data}

This study focuses on the case of Sverdlovsk region in Russia, which comprises 73 municipalities - 68 urban districts and 5 municipal districts.

The choice of indicators was determined by the fact that any area can be seen from the perspective of its potential users as a place to live and work in and as a place of attraction, that is, as a source of opportunities for leisure and recreation. Elements of social infrastructure can be classified the same way: amenities and benefits for living and work; infrastructure for sport and leisure.

In this study, we decided to focus on the social infrastructure used by people in their daily lives (we use the supply of new housing as an indicator) and the infrastructure that turns certain spots into places of attraction (for example, the number of stadiums with terraces). We did not consider infrastructure objects that are necessary for creating a comfortable working environment, although the proposed methodology would make it possible to consider those as well. Moreover, this methodological approach can be applied to analyze the spatial distribution of infrastructure elements of other types, for instance, those unrelated to the social sphere or linked to other indicators such as cultural facilities, public improvements and so on. As an indicator characterizing settlement patterns, we took the number of permanent residents in the municipalities of the region.

In order to obtain the necessary data on the population, new housing supply and the number of stadiums with terraces for specific municipalities, we used the database ${ }^{2}$ of the Federal State Statistics Service. The study period was one year - 2017 .

The study comprised several stages: at the first stage, we focused on the settlement patterns in the region and searched for correlations between the population size of neighbouring municipalities. Thus, we were able to identify clusters within the regional settlement system. At the second stage, we investigated the distribution of specific elements of infrastructure across the region and its correlation with the settlement patterns.

Methodologically, this study relies on calculations for Moran's I and map-based analysis.

${ }^{2}$ Official website of the Federal State Statistics Service. Database of municipal indicators. Retrieved from: http://www. gks.ru/dbscripts/munst/ 
We calculated the parameters of spatial autocorrelations (based on Moran's test) by following the procedure described below.

First, a distance matrix was generated. The matrix shows the distances between all the given territorial units. Entries for the matrix can be determined in different ways: for example, an entry may be equal to 0 (if the territories do not share a border) or 1 (if they do). Entries can be also determined by using aerial distance data, the length of the roads or railways between the territories in question.

We built the distance matrix by using the data on the length of the roads connecting administrative centres of the municipalities. The region has three municipalities whose administrative centres are located outside their borders and, therefore, coincide with the administrative centres of the neighbouring municipalities (Kamensky and Krasnoufimsk urban districts, Kamyshlovsky municipal district). The distance between these municipalities and the neighbours which they share their 'capital' with was taken as 0.

Second, we calculated the global Moran's I and looked for the spatial autocorrelation or its absence.

The formula for the global Moran's I (1) looks the following way:

$$
I=\frac{n \sum_{i=1}^{n} \sum_{j=1}^{n} w_{i j}\left(x_{i}-\bar{x}\right)\left(x_{j}-\bar{x}\right)}{S_{0} \sum_{i=1}^{n}\left(x_{i}-\bar{x}\right)^{2}},
$$

where $I$ is the global Moran's I, $x$ is the given parameter, $S_{0}$ is the sum of spatial weights $\left(S_{0}=\sum_{i=1} \sum_{j=1} w_{i j}\right)$,
and $n$ is the number of territories.

The index values may vary between -1 and 1 . We need to compare the actual value with the expected value (2) to make a conclusion about the presence or absence of spatial autocorrelation and its character.

$$
E(I)=\frac{-1}{n-1},
$$

where $E(I)$ is the expected value and $n$ is the number of territories.

These values can be interpreted the following way. If the calculated value of Moran's I exceeds the expected value, we observe a positive spatial autocorrelation (the values of the given indicator for neighbouring areas are similar or close to each other); if the expected value exceeds the value of Moran's I, it means that there is a negative spatial autocorrelation (the values of the given indicator for neighbouring areas are different). If the expected value of Moran's I coincides with the actual value, it means the absence of spatial autocorrelation [21].

To test for significance of Moran's I, we use a z-test - a traditional procedure for hypothesis testing in econometrics. The z-score for Moran's global $\mathrm{I}$ is calculated by applying the following formula:

$$
z \text {-score }=\frac{I-E(I)}{\sqrt{E\left(I^{2}\right)-E(I)^{2}}},
$$

where $I$ is the global Moran's I and $E(I)$ is the expected value.

The $z$-score thus obtained is the measure of how many standard deviations above or below the expected value the actual value of Moran's I is. If the above value is sufficiently high, it means that the actual distribution did not occur by chance.

Third, we calculate the local Moran's I and find the strength of correlation between the territories.

The local Moran's I shows the interdependence between the territories and its strength [25, p. 147]. The local Moran's I can be calculated by applying formula (4):

$$
I_{L_{i}}=z_{i} \sum w_{i j} z_{j}
$$

where $I_{L_{i}}$ is the local Moran's I for the ith territory, $w_{i j}$ is the standardized distance between the $i t h$ and $j$ th territories, $z_{i}$ and $z_{j}$ are the standardized values of the given indicator for the $i t h$ and $j t h$ territories.

The values we obtain may be negative (minimum -1) or positive (maximum 1) and can be interpreted by following the same logic as for the global Moran's I.

It is also interesting to look at the separate components of local index (5), whose values characterize the strength of interdependence between the two territories [18]:

$$
L I S A_{i j}=z_{i} z_{j} w_{i j}
$$

where $L I S A_{i j}$ is the strength of interdependence between the ith and the $j$ th areas, $w_{i j}$ is the standardized distance between the $i$ th and $j$ th areas, $z_{i}$ and $z_{j}$ are the standardized values of the given indicator for the ith and $j$ th areas.

Fourth, the territories are grouped according to the correlation between the standardized values of the given indicators and the values of the spatial factor.

If we combine the standardized values of the given indicator $(z)$ with its spatial centred weights $\left(w_{z}\right)$ for each given territory within one system of 
axes, we can notice that the points (corresponding to the territorial units) concentrate in one of the four quadrants $[24$, p. 50].

If values $\mathrm{z}$ and $w_{z}$ are positive (quadrant $\mathrm{HH}$ ), it means that territories characterized by high values in the given indicator are clustered with adjacent territories, which also demonstrate high values. If values $\mathrm{z}$ and $w_{z}$ are negative (quadrant LL), it means that the territories are located near other areas with similar values in the given parameter, but in both cases the territories demonstrate a low level of performance in the given indicator. If value $z$ is positive while value $w_{z}$ is negative (quadrant HL), the territory is different from its neighbours - it is ahead of the adjacent territories in this indicator. If value $\mathrm{z}$ is, on the contrary, negative, while value $w_{z}$ is positive (quadrant $\mathrm{LH}$ ), the territory lags behind its neighbours. Thus, territories with a positive autocorrelation fall within the quadrants $\mathrm{HH}$ and LL, with negative autocorrelation - quadrants HL and LH. Such grouping demonstrates the place of each territorial unit in this spatial system, shows its leaders (extrema) and peripheral areas and allows us to make spatial clustering.

The map helps us display the results of spatial data analysis and complements other research methods. Maps can be used as spatial models of real-life situations, illustrating the already existing or planned structures and relationships in a socio-economic space. If we add new information to the map (symbols and pictograms characterizing the localization of the objects, lines in different thicknesses to show the strength of interdependence between the specific territories, different colours to highlight some parts of the map, and so on), we can show subtle trends, relationships and correlations.

\section{Results and discussion}

The population density in Sverdlovsk region (the map of the region with its municipalities is shown in Figure 1) is uneven, with $34.7 \%$ of the population living in the region's administrative centre - Ekaterinburg. The population of the urban agglomeration of Ekaterinburg (its boundaries are defined by the Territorial Planning Scheme of Sverdlovsk region ${ }^{3}$ ) is over 2,242 thousand people or $51.8 \%$ of the total population of the region.

\footnotetext{
${ }^{3}$ Decree of the Government of Sverdlovsk Region No. 1000-PP of August 31, 2009 'On the Approval of the Territorial Planning Scheme of Sverdlovsk Region'. Retrieved from: http:// docs.cntd.ru/document/895218020
}

It should be noted that the size of the area of the region's constituent municipalities is only $6.8 \%$ of the total area of Sverdlovsk region ${ }^{4}$.

In order to estimate spatial autocorrelation, we analyzed the data on the population of municipalities in Sverdlovsk region and found that there is an inverse relationship between the values of this indicator for nearby localities: the actual value of the global Moran's I (-0.021) is smaller than the expected value, which means that there is a negative autocorrelation. The significance of this result is confirmed by the z-test. This means that the population size varies significantly from municipality to municipality. It should be noted, however, that negative values of Moran's I can be explained by the sheer size of the largest municipality - Ekaterinburg: it differs considerably not only from the region's average but also from its nearest neighbours, even though many nearby territories have quite large populations. The local Moran's I for Ekaterinburg is -0.010 , which means that if we exclude this municipality from our calculations, the value of the global Moran's I (for the whole region) will exceed the expected value.

The values of local indices calculated with the help of formula (4) show that large municipalities, such as Ekaterinburg, Nizhny Tagil, and Kamensk-Uralsky, differ significantly from their neighbours. The same applies to the municipalities located in closest proximity to these cities (see Table 1). Thus, we can suppose that Ekaterinburg, Nizhny Tagil and Kamensk-Uralsky concentrate most population in the region (extrema) and that they are the leaders of their respective territorial clusters.

Table 1

Municipalities characterized by negative values of the local Moran's I

\begin{tabular}{|l|c|l|c|}
\hline \multicolumn{1}{|c|}{ Municipality } & $\boldsymbol{I}_{\boldsymbol{L}_{i}}$ & \multicolumn{1}{c|}{ Municipality } & $\boldsymbol{I}_{\boldsymbol{L}_{i}}$ \\
\hline Ekaterinburg & -0.010 & Degtyarsk & -0.001 \\
\hline Kamensky & -0.003 & Closed settlement & -0.001 \\
\hline Kamensk-Uralsky & -0.002 & 'Uralsky' & \\
\hline Nizhny Tagil & -0.002 & Verkhnee Dubrovo & -0.001 \\
\hline Gornouralsky & -0.002 & Verkh-Neyvinsky & -0.001 \\
\hline Sredneuralsk & -0.001 & Aramilsky & -0.001 \\
\hline
\end{tabular}

The table does not include the data on those municipalities whose values of the local Moran's I are negative but are closer to 0 than to -0.001 .

${ }^{4}$ Official website of the Federal State Statistics Service. Database of municipal indicators. Retrieved from: http://www. gks.ru/dbscripts/munst/ 
In order to make a more solid conclusion about the spatial characteristics of the settlement system in Sverdlovsk region, we need to group the territories according to the correlation between the standardized values of the indicator and the values of the spatial factor. Moran's diagram of spatial dispersion (Figure 2) illustrates the distri- bution of $z$ points in the system of axes $z$ and $w$. Each point corresponds to one of the municipalities. The three points located to the right of the vast majority of points are the obvious leaders we have already identified above.

Nevertheless, along with the easily identified extrema, there are other municipalities in the

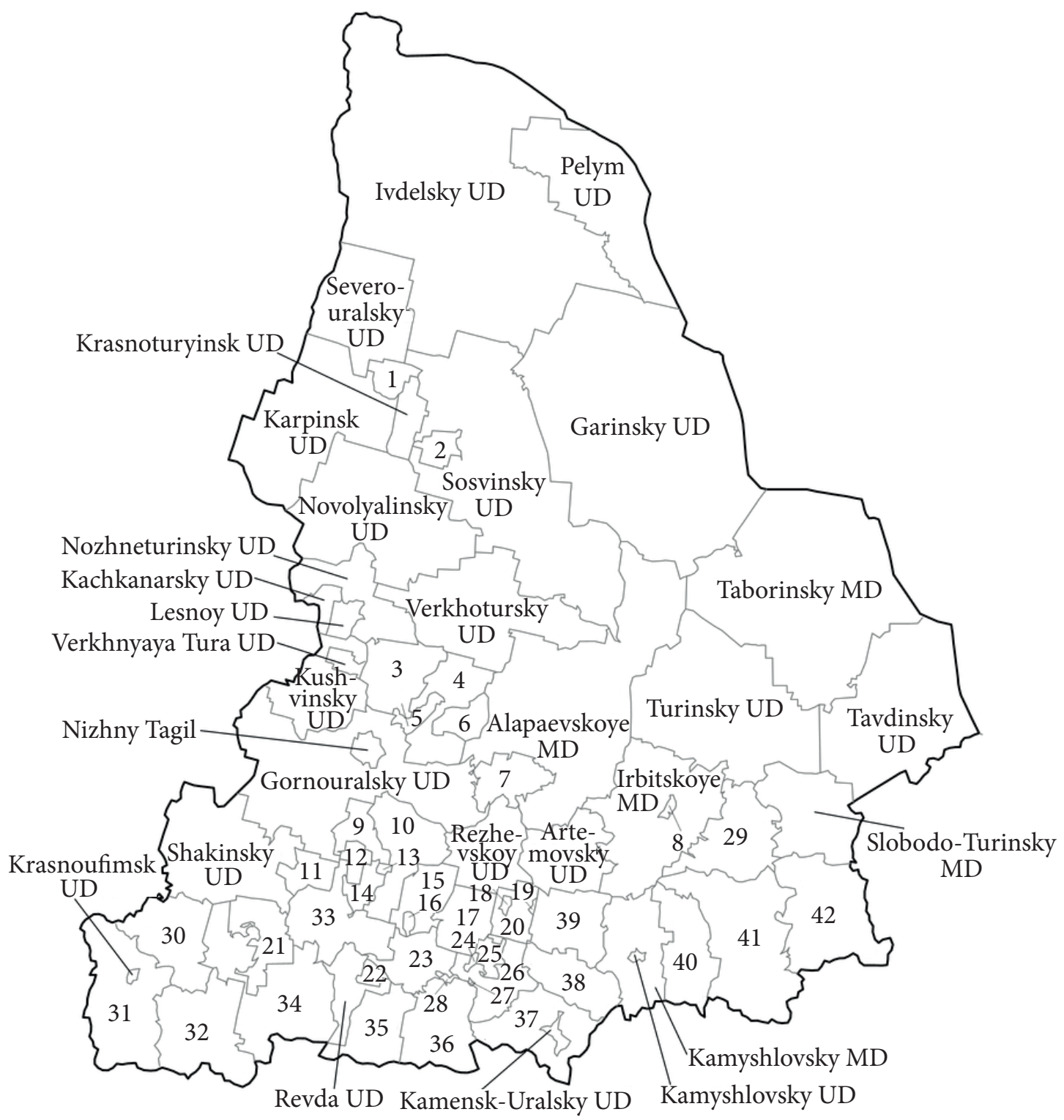

1 - Volchansky urban district; 2 - Serovsky urban district; 3 - Krasnouralsk urban district; 4 - Verkhnesaldinsky urban district; 5 - closed settlement Svobodny; 6 - NizhnyayaSalda urban district; 7 -Alapaevsk municipal district; 8 - Irbit municipal district; 9 - Kirovgradsky urban district; 10 - Nevyansky urban district; 11 - Staroutkinsk urban district; 12 - Nizhny Tagil urban district; 13 - Verkh-Neyvinsky urban district; 14 - Novouralsky urban district; 15 - Verkhnyaya Pyshma urban district; 16 - Sredneuralsk urban district; 17 - Berezovsky urban district; 18 - Malyshevsky urban district; 19 - Reftinsky urban district; 20 - Asbestovsky urban district; 21 - Bisertsky urban district; 22 - Degtyarsk urban district; 23 - Ekaterinburg urban district; 24 - Verkhnee Dubrovo urban district; 25 - Zarechny urban district; 26 - Beloyarsky urban district; 27 - closed settlement Uralsky; 28 - Aramilsky urban district; 29 - Baikalovsky municipal district; 30 - Achitsky urban district; 31 - Krasnoufimsky municipal district; 32 - Artinsky urban district; 33 - Pervouralsk urban district; 34 - Nizhneserginsky municipal district; 35 - Polevskoy urban district; 36 - Sysertsky urban district; 37 - Kamensky urban district; 38 - Bogdanovich urban district; 39 - Sukhoy Log urban district; 40 - Pyshminsky urban district; 41 - Talitsky urban district; 42 - Tugulymsky urban district

Figure 1. Municipalities of Sverdlovsk region 
HL group (areas with a higher population concentration than their neighbours) such as Serov, Novouralsk and Krasnoturyinsk (Table 2). Their values of spatial autocorrelation are too close to zero, which means that their impact on the surrounding territories is insignificant.
One more group of municipalities with relatively large populations (and positive autocorrelation values) includes seven territories (group $\mathrm{HH}$ ). These municipalities do not qualify as centres of the settlement system and, therefore, they do not dominate the surrounding territories. At

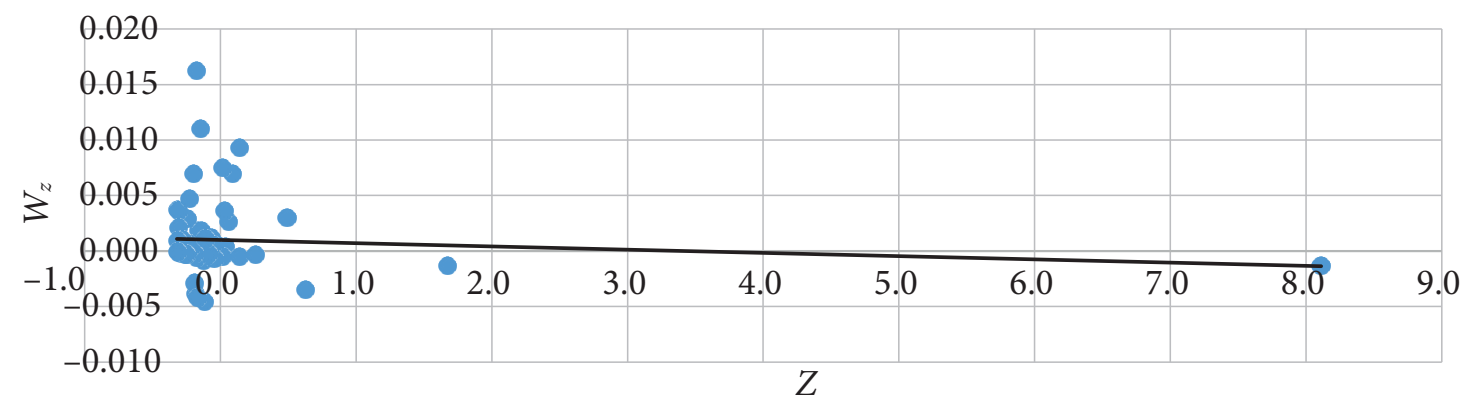

Figure 2. Moran's diagram of spatial dispersion (parameter - 'resident population size')

Table 2

Groups of municipalities with different positions in the regional settlement system

\begin{tabular}{|c|c|c|c|}
\hline Municipality & $I_{L_{i}}$ & Municipality & $I_{L_{i}}$ \\
\hline \multicolumn{2}{|l|}{ LH } & \multicolumn{2}{|l|}{ HH } \\
\hline Kamensky urban district & -0.0029 & Pervouralsk urban district & 0.0015 \\
\hline Gornouralsky urban district & -0.0016 & Verkhnyaya Pyshma urban district & 0.0013 \\
\hline Sredneuralsk urban district & -0.0014 & Berezovsky urban district & 0.0006 \\
\hline Closed settlement 'Uralsky' & -0.0012 & Polevskoy urban district & 0.0002 \\
\hline VerkhneeDubrovo urban district & -0.0011 & Sysertsky urban district & 0.0001 \\
\hline Aramilsky urban district & -0.0011 & Revda urban district & 0.0001 \\
\hline Degtyarsk urban district & -0.0007 & Asbestovsky urban district & 0.0000 \\
\hline Verkh-Neyvinsky urban district & -0.0006 & & \\
\hline Zarechny urban district & -0.0003 & & \\
\hline Staroutkinsk urban district & -0.0003 & & \\
\hline Bysertsky urban district & -0.0003 & & \\
\hline Beloyarsky urban district & -0.0003 & & \\
\hline Malyshevsky urban district & -0.0002 & & \\
\hline Closed settlement 'Svobodny' & -0.0002 & & \\
\hline VerkhnyTagil urban district & -0.0002 & & \\
\hline Reftinsky urban district & -0.0002 & & \\
\hline Kirovgradsky urban district & -0.0001 & & \\
\hline Nizhneserginsky municipal district & -0.0001 & & \\
\hline Nevyansk urban district & -0.0001 & & \\
\hline Shalinsky urban district & -0.0001 & & \\
\hline Rezhevskoy urban district & -0.0001 & & \\
\hline Bogdanovich urban district & -0.0001 & & \\
\hline Artinsky urban district & -0.0001 & & \\
\hline NizhnyayaSalda urban district & -0.0001 & & \\
\hline Sukhoy Log urban district & 0.0000 & & \\
\hline Achitsky urban district & 0.0000 & & \\
\hline Alapaevskoye municipal district & 0.0000 & & \\
\hline Makhnevskoye municipal district & 0.0000 & & \\
\hline Alapaevsk urban district & 0.0000 & & \\
\hline Artemovsky urban district & 0.0000 & & \\
\hline Verkhnesaldinsky urban district & 0.0000 & & \\
\hline \multicolumn{2}{|l|}{$\mathbf{L L}$} & \multicolumn{2}{|l|}{ HL } \\
\hline Other municipalities & & Ekaterinburg & -0.0104 \\
\hline
\end{tabular}


the same time, they have large populations, which means that we cannot consider them simply as peripheral areas. It would be more appropriate to refer to them as constituent parts of agglomerations, elements of the area of population concentration. These also include those urban districts (Pervouralsk, Verkhnyaya Pyshma, and Berezovsky) which have closer relations with their neighbours than other municipalities in this group (their values of the local Moran's I are the highest).

The LH group includes municipalities with comparatively low values in the given indicator, located in proximity with densely populated territories and thus inevitably influenced by these neighbours. Eight of these municipalities (placed at the top of the corresponding part of the table) are more closely connected with the neighbouring municipalities (these municipalities are the most influential ones) than with others.
All other municipalities in the region (not included in any of the groups) have a positive autocorrelation (which means a certain similarity to their neighbours) and have relatively low values of the population size. These are included into the LL group: they are neither influenced by their neighbours nor influence their neighbours themselves.

The map in Figure 3 illustrates these results. The four groups of municipalities are highlighted by different colours and the saturation of the colour depends on how closely these municipalities interact with their neighbours: red, dark green or dark yellow are used for municipalities with the highest values of the local Moran's I in their respective groups. The territories with strongest interdependence are connected by lines (we used formula 5 to assess the strength of influence between the two possible pairs of territories).

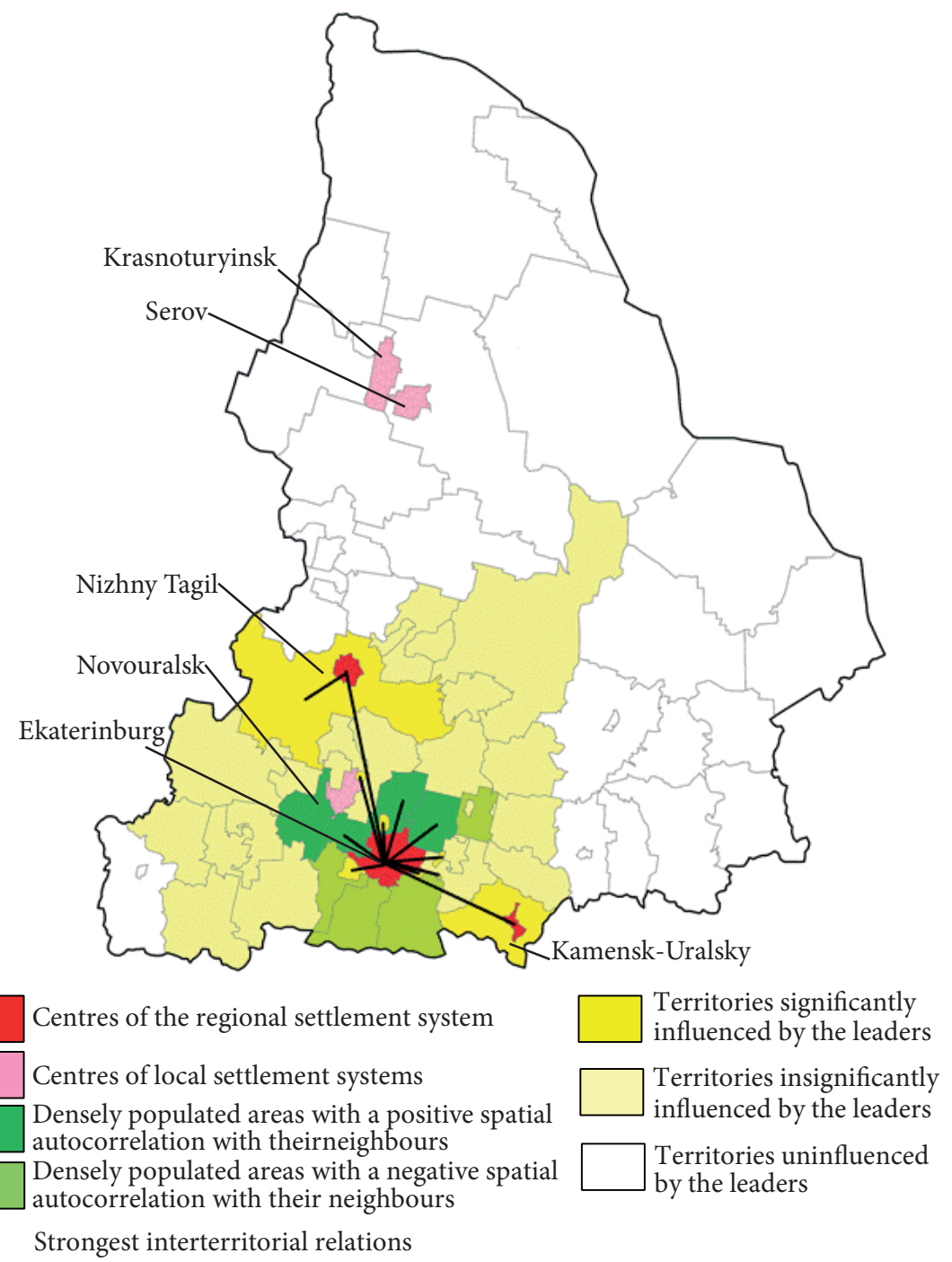

Figure 3. Spatial autocorrelation between municipalities in Sverdlovsk region (parameter - 'resident population size') 
These results confirm our previous conclusion that the population distribution across Sverdlovsk region is uneven: the region has three extrema with large populations and these municipalities are surrounded by other territories, which are also quite densely populated (areas of population concentration). The centres of the regional settlement system (and the surrounding areas of influence) are located in the south-western part while the rest of the region looks like a 'desert', comprising scarcely populated municipalities. Although some researchers expect the city of Serov in the north of the region to evolve into a full-fledged urban agglomeration [26; 27], it is still too early to speak of it as a newly emerged centre in the regional settlement system. Serov and Krasnoturyinsk have much larger populations than the surrounding territories, which turns them into local leaders, although their resources are not sufficient for scaling up their activities and for creating an agglomeration effect.

Parameters of spatial autocorrelation identified through the analysis of infrastructure localization are slightly different from the previously identified strength of correlations between the resident populations of the given municipalities.

The value of the global Moran's I (0.025) exceeds its expected value: we observe a positive spatial autocorrelation, which means that in general there are no significant disparities between the development of the neighbouring territories. What we see is a gradual change in the given indicators.

An undisputed leader in terms of new housing supply is Ekaterinburg. The neighbouring territories are behind Ekaterinburg but they still tend to perform above the average level in the region. Therefore, Ekaterinburg together with the adjacent territories (group $\mathrm{HH}$ ) form an area characterized by intensive construction of new housing (see Table 3). As Table 3 illustrates, the strongest correlations between the values of this indicator for this area are observed for Ekaterinburg, Berezovsky, Sysert and Verkhnyaya Pyshma.

Table 3

Leaders in new housing supply

\begin{tabular}{|l|l|r|}
\hline Group & \multicolumn{1}{|c|}{ Municipality } & \multicolumn{1}{c|}{$\boldsymbol{I}_{\boldsymbol{L}_{\boldsymbol{i}}}$} \\
\hline HH & Verkhnyaya Pyshma & 0.0065 \\
\cline { 2 - 3 } & Berezovsky & 0.0061 \\
\cline { 2 - 3 } & Ekaterinburg & 0.0059 \\
\cline { 2 - 3 } & Sysert & 0.0044 \\
\cline { 2 - 3 } & Beloyarsky & 0.0010 \\
\cline { 2 - 3 } & Pervouralsk & 0.0009 \\
\cline { 2 - 3 } & Sredneuralsk & 0.0006 \\
\cline { 2 - 3 } & Kamensk-Uralsky & 0.0000 \\
\hline HL & Nizhny Tagil & -0.0001 \\
\hline
\end{tabular}

In the HL group (territories whose rates of new housing supply are considerably higher than in the neighbouring municipalities), only one municipality - Nizhny Tagil - can be considered to be a local leader, able to compete (though not very successfully) with Ekaterinburg and its surroundings.

The majority of municipalities in these groups are characterized by a negative autocorrelation (group LH) since their performance in this indicator is not very high while their proximity to the top municipalities means that they are influenced by these leaders. The LL group again includes those municipalities which account for over a half of the region's total area, primarily, its northern and eastern parts (Figure 4).

If we compare the results shown in Figure 3 and Figure 4, we shall see that in general municipalities with positive spatial autocorrelation in the two given parameters demonstrate the following trend: areas with a high concentration of population and objects of infrastructure (including the zones of influence surrounding these objects) are located in the south-western part of the region while its northern and eastern parts are maximally remote (not only geographically but also regarding the specific aspects of territorial development) from the regional leaders.

At the same time our analysis of spatial autocorrelation has brought to light a significant difference between the spheres in question. The adjacent municipalities may differ considerably in terms of the population size while the difference between their rates of new housing supply is usually not that substantial, which can be explained by the differences inherent in the nature of the phenomena in question. The population size results from the impact of a whole set of complex socio-economic processes while the data on new housing (characterizing the process as such) correlate with the economic parameters of territorial development and are driven by market factors.

The demand in the housing market is to a great extent determined by the number of potential buyers - local residents. Nevertheless, housing developers' decision-making depends even more on the trends in the sphere of land use planning and development. Those who build infrastructure for this or that residential space seek to maximize their profits and occupy new market niches. In doing so, they try to predict in what direction the transformation of the settlement system in this territory will be heading and at the same time 
adjust this transformation to their needs. Transformations of agglomerations mostly involve the development of the territories surrounding the centre, which means that new living spaces tend to emerge within the boundaries of these territories rather than beyond them. In their turn, the territories which do not play a significant role in the settlement system and hold little potential in this respect continue to rank low in the regional system of living spaces.

Analysis of the data on places of attraction (for example, stadiums with terraces) built in the region shows a negative spatial autocorrelation (there are differences in the given indicators be- tween the adjacent territories): the global Moran's I is 0.058 . We have thus arrived at some interesting results (see Figure 5).

First, the distribution of the given infrastructure objects across the region cannot be called even, although fewer municipalities are uninfluenced by the regional leaders (in comparison with the distribution of population and new housing considered above).

Second, the number of centres (mostly local) where stadiums are built (HL group) is quite large (23). The factor that influenced the results of this study is that the number of stadiums in the region (or equivalents thereof) is insignificant.

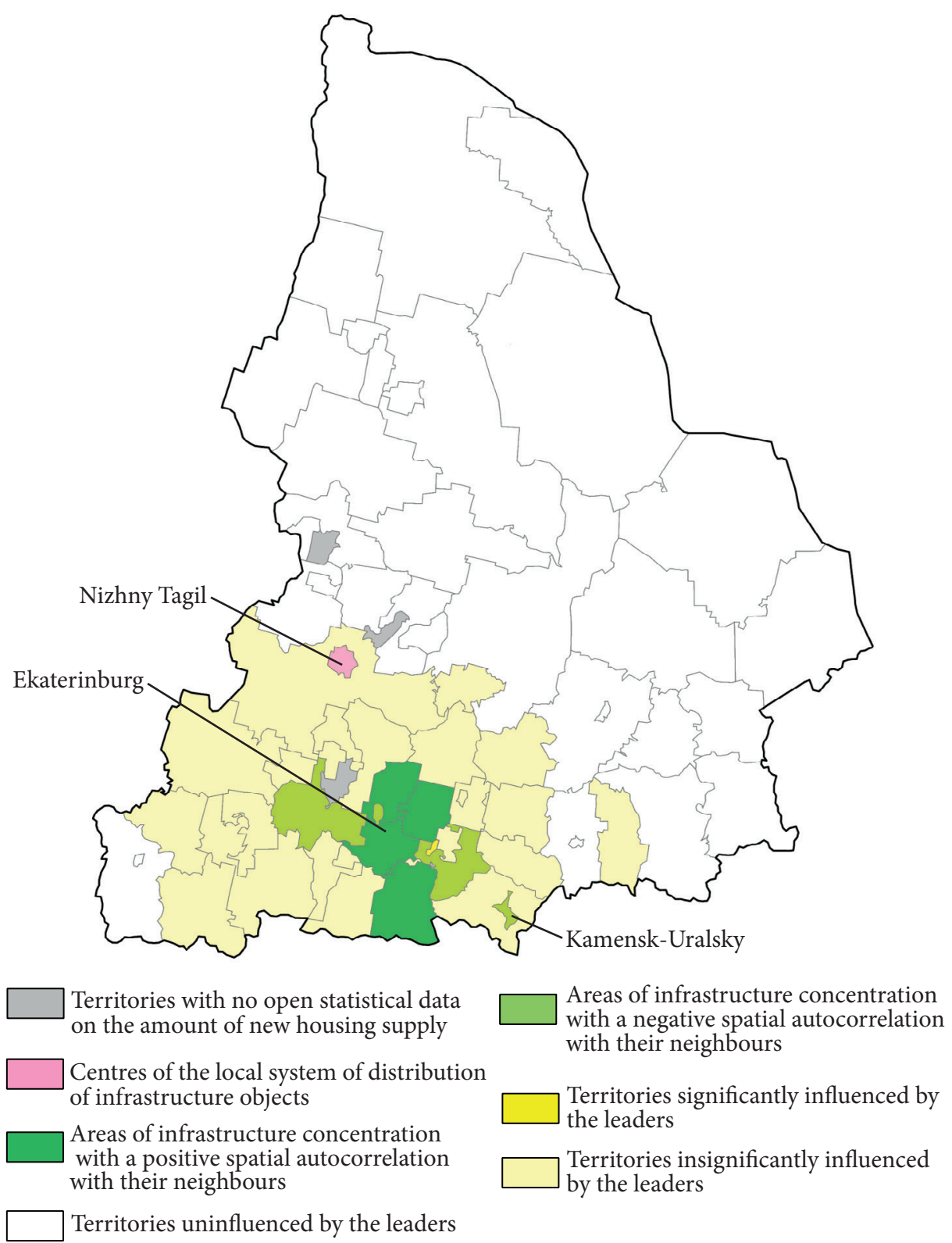

Figure 4. Spatial autocorrelation between municipalities in Sverdlovsk region (parameter - 'new housing supply') 
Third, the proximity of certain municipalities without stadiums of their own to the areas with stadiums enabled them to join the zone of influence created by the leaders (that is, municipalities which have at least one stadium), which means that inhabitants of the former can enjoy access to the infrastructure of the latter.

If we look at the maps in Figure 3 and Figure 5 , we can notice that, despite the perceived differences in the distribution of infrastructure across municipalities (location of stadiums), there are certain correlations in terms of infrastructure concentration (concentration areas are located in the south-western part of the region), location of hubs in urban districts, such as Nizhny Tagil and Kamensk-Uralsky, and the settlement system.

The difference between the spatial characteristics of the infrastructure in residential areas and places of attraction (Figure 4 and Figure 5) is even more significant. This can be explained by the fact that it is usually the local authorities who initiate the building of such objects as stadiums and their further development, because these projects are not considered profitable by local businesses (except for large stadiums in big cities) and, therefore, do not attract much private investment. Thus, the distribution of such objects in space is determined not so much by the economic factors

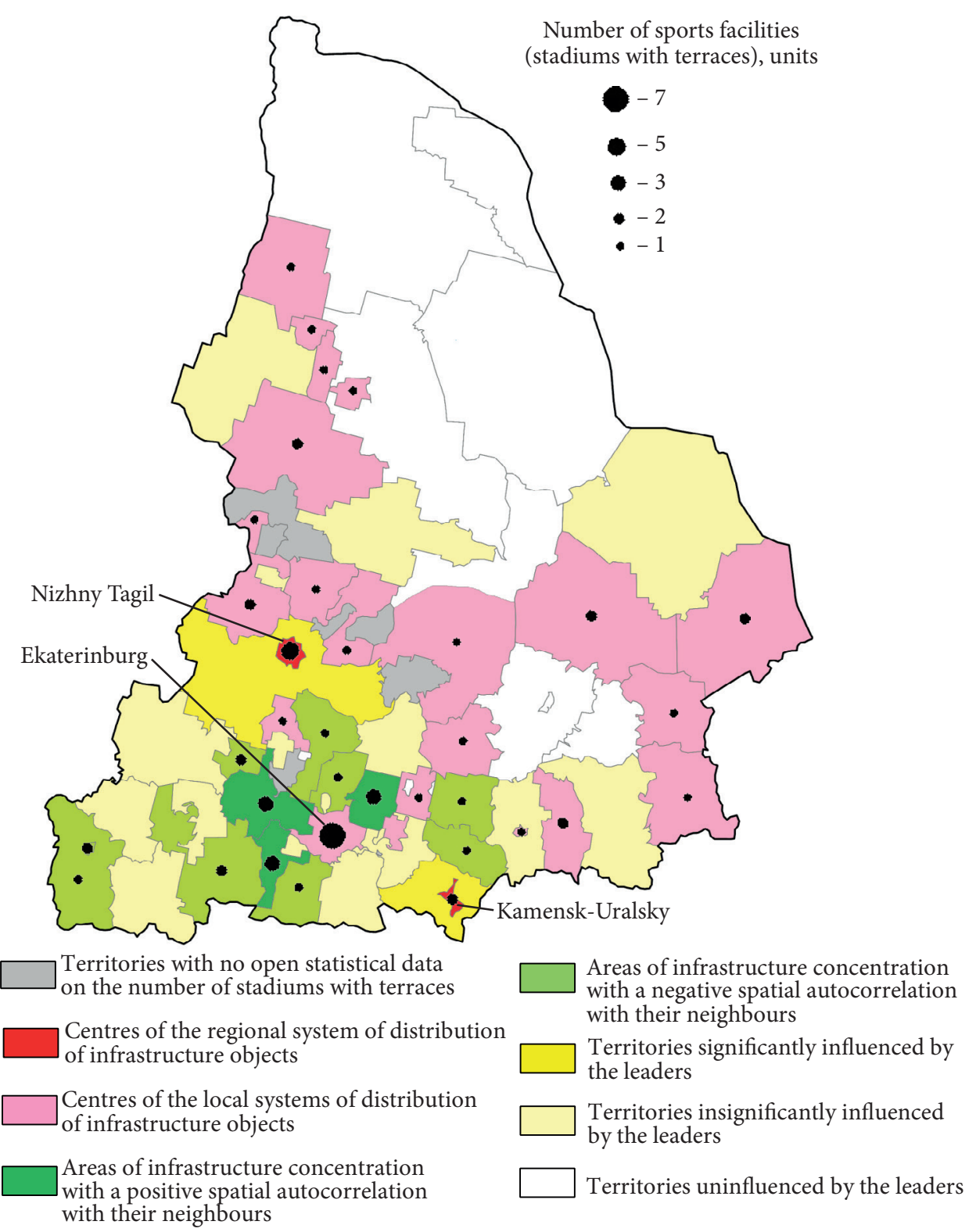

Figure 5. Spatial autocorrelation between municipalities in Sverdlovsk region (parameter - 'number of stadiums with terraces') 
but by social factors such as the standards of infrastructure provision (determined by the current demographic characteristics of the area), residents' needs and expectations.

\section{Conclusion}

Scholarly interest in spatial socio-economic systems of different levels and their dynamics as well as the need for efficient regional policy-making has led to the development of a comprehensive system of analytical methods. These methods are applied for analysis of the localization of objects and its characteristics, spatial aspects of territorial transformations, and problems of spatial development. Characteristics of regional settlement systems, infrastructure distribution and the relationship between them can be studied with the help of spatial autocorrelation analysis combined with map analysis.

In our study we revealed a correlation between the patterns of distribution of different social infrastructure elements in Sverdlovsk region and the region's settlement patterns, which can be explained by the fact that these objects of infrastructure attract their potential users, thus increasing the population concentration in these areas. Distribution and concentration of infrastructure of different types is determined by various factors, and, therefore, the infrastructural systems can meet the needs of local residents to a greater or lesser extent. For example, the spatial organization of the regional infrastructure, its emergence and further transformations stem from the need to generate economic effects and, therefore, correlate to a greater extent with the prospective transformations of the settlement system rather than with its current characteristics. Since it is regional and local authorities who are in charge of building places of attraction, the localization of such infrastructure correlates more with the current settlement system.

Formation and transformation of the region's infrastructural framework can contribute to levelling the differences between the territories and thus enhance the shrinkage of space and its defragmentation (provided that the key factor of such transformation is the agglomeration processes and the changes they cause). Territorial infrastructure should be able to respond promptly to the region's needs in spatial development, which makes monitoring of the qualitative and quantitative characteristics of the infrastructure vitally important.

\section{References}

1. Thünen, J. (1826). Der isolirte Staat in Beziehung auf Landwirtschaft und Nationalökonomie. Hamburg: Wirtschaft \& Finan.

2. Weber, A. (1922). Standort der Industrien. Tubingen.

3. Losch, A. (1954). The Economics of Location. New Haven: Yale University Press.

4. Christaller, W. (1980). Die zentralen Orte in Süddeutschland. Eineökonomisch-geographische Untersuchungüber die Gesetzmäßigkeit der Verbreitung und Entwicklung der Siedlungen mit städtischer Funktionen. Wissenschaftliche Buchgesellschaft, Darmstadt.

5. Launhardt, W. (1882). Die Bestimmung des zweckmässigsten Standortes einer gewerblichen Anlage. Zeitschrift des Vereinesdeutscher Ingenieure, 26, 106-115.

6. Boudeville, J. (1968). L'espace et les Pôles de Croissance. Paris: PUF.

7. Perroux, F. (1954). L'Europe sans Rivages. Grenoble: Presses universitaires de Grenoble.

8. Friedmann, J. (1986). The World city hypothesis. Development and Change, 4, 12-50.

9. Fujita, M., Krugman, P., \&Venables, A. J. (1999). The Spatial Economy: Cities, Regions, and International Trade. Cambridge: The MIT Press.

10. Nekrasov, N. N. (1978). Regional Economy: Theory, Problems, Methods. Moscow: Ekonomika. (In Russ.)

11. Aleksandrov, I. G. (1921). Economic Zoning of Russia. Moscow. (In Russ.)

12. Probst A.E. (1965). Efficiency of Territorial Organization of Production: Methodological Essays. Moscow: Mysl. (In Russ.)

13. Tatarkin, A. I., \& Animitsa, E. G. (2012). Formation of the paradigm theory of the regional economy. Economy of Region, 3, 11-21. (In Russ.)

14. Moran, P. (1948). The interpretation of statistical maps. Journal of the Royal Statistical Society, 10(2), 243-251. 
15. Geary, R. (1954). The continiguity ratio and statistical mapping. The Incorporated Statistician, 5, 115-145.

16. Cliff, A., \& Ord, J. K. (1981). Spatial Processes: Model, and Application. London: Pion.

17. Anselin, L. (1988). Spatial Econometrics: Methods and Models. Dordrecht: Kluwer Academic.

18. Pavlov, Ju. V., \& Koroleva E. N. (2014). Spatial interactions: estimation based on global and local Moran indexes. Spatial Economics, 3, 95-110. (In Russ.)

19. Grigoriev, A. A. (2018). Spatial autocorrelation of educational attainment in the Russian Federation. Psychology. Journal of Higher School of Economics, 15(1), 164-173. (In Russ.) DOI: 10.17323/1813-8918-2018-1-164-173

20. Demidova, O., \& Signorelli, M. (2012). Determinants of youth unemployment in Russian regions. Post-Communist Economies, 24(2), 191-218.

21. Balash, O. S. (2012). Statistical research of the spatial clustering of regions of Russia. News of Tula State University. Economic and Legal Sciences, 2-1, 56-65. (In Russ.)

22. Inozemcev, E. S., \& Kochetygova, O. V. (2018). Spatial panel analysis of fertility and life expectancy in Russia. Izv. Saratov Univ. (N. S.), Ser. Economics. Management. Law, 18 (3), 314-321. (In Russ.) DOI: 10.18500/1994-25402018-18-3-314-321

23. Hubert, L. J., Golledge R. G., \& Costanza C. M. (1981). Generalized procedures for evaluating spatial autocorrelation. Geographical Analysis, 13, 224-233. DOI: 10.1111/j.1538-4632.1981.tb00731.x

24. Geography, Institutions and Regional Economic Performance. (2012). In R. Crescenzi, \& M. Percoco (Eds.). Berlin: Springer Science \& Business Media.

25. Rusanovskiy, V. A., \& Markov, V. A. (2016). The effect of a spatial factor on regional differentiation of unemployment in the Russian economy. Studies on Russian Economic Development, 5, 144-157. (In Russ.)

26. Averkieva, K. V., Antonov, E. V., Denisov, E. A., \& Faddeev, A. M. (2015). Spatial structure of the urban system of the North of Sverdlovsk oblast. Bulletin of the Russia Academy of Sciences. Geographical series, 4, 24-38.

27. Izhguzina, N. R. (2017). The calculation of synergistic effect of urban agglomerations (exemplified by Sverdlovsk oblast). Journal of the Ural State University of Economics, 2(70), 75-89. (In Russ.)

\section{Information about the authors}

Julia G. Lavrikova - Doctor of Economics, Associate Professor, Director of the Institute of Economics, Ural Branch of Russian Academy of Sciences (29 Moskovskaya St., 620014, Ekaterinburg, Russia); e-mail: lavrikova_ug@mail.ru

Arina V. Suvorova - Candidate of Economics, Deputy Director for Research of the Institute of Economics, Ural Branch of Russian Academy of Sciences, Associate Professor, Department of Regional, Municipal Economy and Management, Ural State University of Economics (29 Moskovskaya St., 620014, Ekaterinburg, Russia); e-mail: av_suvorova_av@mail.ru

ARTICLE INFO: received July 2, 2019; accepted September 10, 2019

\section{Информация об авторах}

Лаврикова Юлия Георгиевна - доктор экономических наук, доцент, директор, Институт экономики Уральского отделения Российской академии наук (620014, Россия, г. Екатеринбург, ул. Московская, 29); e-mail: lavrikova_ug@mail.ru

Суворова Арина Валерьевна - кандидат экономических наук, врио зам. директора по научной работе, Институт экономики Уральского отделения Российской академии наук, доцент, кафедра Региональной, муниципальной экономики и управления, Уральский государственный экономический университет (620014, Россия, г. Екатеринбург, ул. Московская, 29); e-mail: av_suvorova_av@mail.ru

ИНФОРМАЦИЯ О СТАТЬЕ: дата поступления 2 июля 2019 г.; дата принятия к печати 10 сентября 2019 г.

This work is licensed under a Creative Commons Attribution 4.0 International License

Эта работа лицензируется в соответствии с Creative Commons Attribution 4.0 International License 